\title{
COVID-19 Associated Multisystem Inflammatory Syndrome in Children (MIS-C): A New Pediatric Alert
}

\author{
SS SHOVA $^{\mathrm{a}}$, MI ISLAM ${ }^{\mathrm{b}}$
}

\begin{abstract}
:
Multisystem inflammatory syndrome in children (MIS-C), also termed pediatric multisystem inflammatory syndrome (PMIS) temporally associated with coronavirus disease-2019 (COVID-19) is rare but an emerging alarming condition. Though the exact pathogenesis is unknown, COVID-19 can trigger the condition directly or indirectly via immune complex mediated or antibody-dependent enhancement. Patients with MIS-C can present with persistent fever and a constellation of symptoms including hypotension, multiorgan involvement and elevated inflammatory markers. Presentations of MIS-C have overlapping features of Kawasaki disease (KD), toxic shock syndrome (TSS) and Kawasaki disease shock syndrome. Age of presentation, features of shock and more predilections for myocardial dysfunction can distinguish MIS-C from Kawasaki disease.
\end{abstract}

\section{Introduction:}

Coronavirus disease-2019 (COVID-19) caused by severe acute respiratory syndrome coronavirus 2 (SARS-CoV2) has led to a global crisis, affecting individuals of all ages residing in most countries in the world. ${ }^{1}$ Epidemiological data showed that children are a small minority who tested positive. Affected children younger than 18 years have been found in only $1.7 \%$ of the USA, $1 \%$ of cases in the Netherlands, and $2 \%$ of the UK. ${ }^{2}$ In Bangladesh, the scenario is slightly different as according to the Institute of Epidemiology Disease Control and Research (IEDCR) confirmed cases of COVID- 19 were $3 \%$ in age $1-10$ years and $7 \%$ in age 11 20 years. ${ }^{3}$ This data indicates that our country's susceptibility to infection in children is more compared to other countries. SARS-CoV-2 infection in children is relatively mild compared to adult patients and often

\footnotetext{
a. Dr. Shamima Sharmin Shova, Consultant Pediatrician, Aalok Health Care \& Hospital, Mirpur, Dhaka-1216.

b. Prof. Mohammad Imnul Islam, Professor of Pediatrics, Department of Pediatrics, Bangabandhu Sheikh Mujib Medical University (BSMMU) Dhaka.
}

Address of Correspondence: Dr. Shamima Sharmin Shova, 463/1,5-A, Eureka Shantineer, South Kafrul, Dhaka Cantonment, Dhaka-1206, Mobile- 01873412999, E-mail: shoovaa@gmail.com Receive: 25 October, 2020

Accepted: 07 July, 2021
Early recognition is essential, followed by prompt admission to the hospital for specialist attention. Admission to a pediatric intensive unit is mandatory for children with hemodynamic instability (shock, arrhythmia), significant respiratory compromise, or other potentially life-threatening complications. It is also necessary to maintain an appropriate follow-up schedule to observe the long-term outcome. The prognosis of PMIS/ MIS-C is uncertain, given that it is a new clinical entity and understanding of the disease is still evolving.

Keywords: Coronavirus disease-2019(COVID-19), Kawasaki disease (KD), Multisystem inflammatory syndrome in children (MIS-C), Toxic shock syndrome (TSS).

(J Bangladesh Coll Phys Surg 2021; 39: 249-260)

DOI: https://doi.org/10.3329/jbcps.v39i4.55946

asymptomatic or minimally symptomatic. ${ }^{4}$ Studies from different countries have confirmed that children's severe illness and fatalities due to COVID-19 are rare. ${ }^{5}$

Several countries are suffering from the COVID-19 pandemic recently reported children hospitalized in the intensive care unit due to a rare pediatric inflammatory multisystem syndrome. A possible temporal association with SARS-COV-2 infection has been hypothesized because a good number of the children tested for SARSCoV-2 infection were either positive by polymerase chain reaction (PCR) or serology. ${ }^{6}$ Most recently, Centers for Disease Control and Prevention (CDC) data from the US reported that 4404 patients were diagnosed with Multisystem inflammatory syndrome in children (MISC). Among them 37 patients found death. ${ }^{7}$

First, on April 7, 2020, a case report from the USA describing a baby who was diagnosed with Kawasaki disease (KD) and also positive for SARS-CoV-2. ${ }^{1} \mathrm{On}$ April 26, a notice was sent to general practitioners in London, UK advising them about the rising numbers of cases of a multisystem inflammatory state in children presenting with overlapping features of toxic shock syndrome (TSS), Kawasaki disease (KD) and Kawasaki disease shock syndrome (KDSS). ${ }^{8}$ Since then, the US, Canada, Italy, Spain, and France have observed an unusually high number of children with these 
overlapping features in pediatric intensive care. . $^{6,9,10}$ These patients have persistent fever and a combination of symptoms including hypotension, multiple organs (e.g., heart, stomach, hematologic, dermatologic and neurologic) involvement and elevated inflammatory markers. $^{2}$

The syndrome has been designated as Multisystem Inflammatory Syndrome in Children (MIS-C), also mentioned as pediatric multisystem inflammatory syndrome (PMIS), pediatric inflammatory multisystem syndrome temporally associated with SARS-CoV-2 (PIMS-TS), pediatric hyperinflammatory syndrome, or pediatric hyperinflammatory shock. ${ }^{11}$

MIS-C is a systemic inflammation having persistent fever and organ dysfunction, which is temporally associated with exposure to COVID-19. ${ }^{12}$ Onset may be delayed or contemporary with ongoing SARS-CoV-2 infection. It may occur several weeks after the initial infection. An exponential rise of this inflammatory syndrome was observed after the COVID 19 curves have plateaued in the pandemic region. ${ }^{13}$

Case Definition: The criteria used for case definition vary slightly between different health organizations report. $6,12,14 ., 15$ The Centers for Disease Control and Prevention (CDC) case definition requires that the child have severe symptoms requiring hospitalization. In contrast, the World Health Organization (WHO) report does not mention such types of symptoms. An advantage of the WHO definition provides more details regarding clinical signs of multisystem involvement. Table I shows case definitions for emerging inflammatory

Table I

Case Definitions for Emerging Inflammatory Condition During COVID-19 Pandemic from the World Health Organization, Royal College of Pediatrics and Child Health, and Centers for Disease Control and Prevention

\begin{tabular}{|c|c|c|}
\hline World Health Organization (WHO) $^{15}$ & $\begin{array}{l}\text { Royal College of Pediatrics and Child } \\
\text { Health (RCPCH) }\end{array}$ & $\begin{array}{l}\text { Centers for Disease Control and } \\
\text { Prevention (CDC) })^{14}\end{array}$ \\
\hline $\begin{array}{l}\text { Children and adolescents } \\
0-19 \text { year of age with } \\
\text { fever }>3 \text { d AND } 2 \text { of the following: } \\
\text { 1. Rash or bilateral nonpurulent } \\
\text { conjunctivitis or mucocutaneous } \\
\text { inflammation signs (oral, hands, or feet) } \\
\text { 2. Hypotension or shock } \\
\text { 3. Features of myocardial dysfunction, } \\
\text { pericarditis, valvulitis, or coronary } \\
\text { abnormalities (including ECHO findings } \\
\text { or elevated troponin/NT-proBNP) } \\
\text { 4. Evidence of coagulopathy (by P.T., } \\
\text { APTT, elevated D-dimers) } \\
\text { 5. Acute gastrointestinal problems } \\
\text { (diarrhea, vomiting, or abdominal pain) } \\
\text { AND } \\
\text { Elevated markers of inflammation such } \\
\text { as ESR, CRP, or procalcitonin. } \\
\text { AND } \\
\text { No other obvious microbial cause of } \\
\text { inflammation, including bacterial sepsis, } \\
\text { staphylococcal or streptococcal shock } \\
\text { syndromes } \\
\text { AND } \\
\text { Evidence of COVID-19 (RT-PCR, } \\
\text { antigen test, or serology positive) or } \\
\text { likely contact with patients with } \\
\text { COVID-19 } \\
\text { Consider this syndrome in children with } \\
\text { features of typical or atypical Kawasaki } \\
\text { disease or toxic shock syndrome }\end{array}$ & $\begin{array}{l}\text { A child presenting with persistent fever, } \\
\text { inflammation (neutrophilia, elevated } \\
\text { CRP, and lymphopenia) and evidence of } \\
\text { single or multiorgan } \\
\text { dysfunction (shock, cardiac, respiratory, } \\
\text { kidney, gastrointestinal, or neurological } \\
\text { disorder) } \\
\text { This may include children fulfilling full } \\
\text { or partial criteria for Kawasaki disease. } \\
\text { Exclusion of any other microbial cause, } \\
\text { including bacterial sepsis, } \\
\text { staphylococcal or streptococcal } \\
\text { shock syndromes, infections associated } \\
\text { with myocarditis such as enterovirus } \\
\text { SARS-CoV-2 PCR test results may be } \\
\text { positive or negative }\end{array}$ & $\begin{array}{l}\text { An individual aged }<21 \text { year } \\
\text { presenting with fever, } \\
\text { laboratory evidence of inflammation, } \\
\text { and evidence of clinically severe illness } \\
\text { requiring hospitalization, } \\
\text { with multisystem ( }>2 \text { ) organ } \\
\text { involvement (cardiac, kidney, } \\
\text { respiratory, hematologic, } \\
\text { gastrointestinal, dermatologic, or } \\
\text { neurological) } \\
\text { Fever }>38.0{ }^{\circ} \text { C for } \geq 24 \text { h or report of } \\
\text { subjective fever lasting } \geq 24 \text { h } \\
\text { Laboratory evidence including, but not } \\
\text { limited to, } \geq 1 \text { of the following: } \\
\text { an elevated CRP, ESR, fibrinogen, } \\
\text { procalcitonin, D-dimer, ferritin, lactic } \\
\text { acid dehydrogenase, or IL-6; } \\
\text { high neutrophils; reduced lymphocytes; } \\
\text { and low albumin } \\
\text { AND } \\
\text { No alternative plausible diagnoses } \\
\text { AND } \\
\text { Positive for current or recent SARS- } \\
\text { CoV-2 infection by RT-PCR, serology, } \\
\text { or antigen test; or COVID-19 exposure } \\
\text { within the } 4 \text { wks. prior to the onset of } \\
\text { symptoms } \\
\text { Additional comments } \\
\text { Some individuals may fulfill full or } \\
\text { partial criteria for Kawasaki disease but } \\
\text { should be reported if they meet the case } \\
\text { definition for MIS-C } \\
\text { Consider MIS-C in any pediatric death } \\
\text { with evidence of SARS-CoV-2 infection }\end{array}$ \\
\hline
\end{tabular}


conditions during the COVID-19 pandemic from World Health Organization (WHO), Royal College of Pediatrics and Child Health (RCPCH) and the Center for Disease Control and Prevention (CDC).

\section{Pathophysiology:}

The pathogenesis is unknown. SARS-CoV-2 can play one of many roles; can cause this condition directly or indirectly. ${ }^{16}$ It suggests that the Kawasaki-like disease mechanism represents post-infectious inflammatory syndrome, which might be an antibody or immunecomplex mediated process. There was little evidence of viral replication in the UK, USA, France, and the Italian cohort. ${ }^{8-11,16}$ It is speculated that an acquired immune response to COVID-19 activates an inflammatory process in genetically susceptible children. Another possible mechanism is an antibody-dependent enhancement, whereby the development of antibodies facilitates viral entry into host cells. ${ }^{6}$ Cytokine storms induced by
COVID-19 are perhaps responsible for this condition. ${ }^{14}$ Figure I shows the pathogenesis of MIS-C. Coronaviruses characteristic's ability to block interferon responses (type I and III) could be liable for late Cytokine release syndrome (CRS) where immune systems struggle to control SARS-CoV-2 viral replication or are overwhelmed by a high initial viral load in children. ${ }^{17}$

The frequent gastrointestinal presentation suggests predominant replication in the gastrointestinal tract by a virus with a known predilection for enterocytes. ${ }^{18}$ Association of Kawasaki-like disease with COVID-19 could support that this virus is responsible for systemic vasculitis by targeting endothelial tissue via angiotensin-converting enzyme 2 (ACE2) receptor. ${ }^{19}$ A leading hypothesis for KD's pathogenesis also involves a hyperinflammatory response to viral infection in genetically susceptible children and that SARS-CoV-2 is now added to the list of implicated viral triggers. ${ }^{20}$

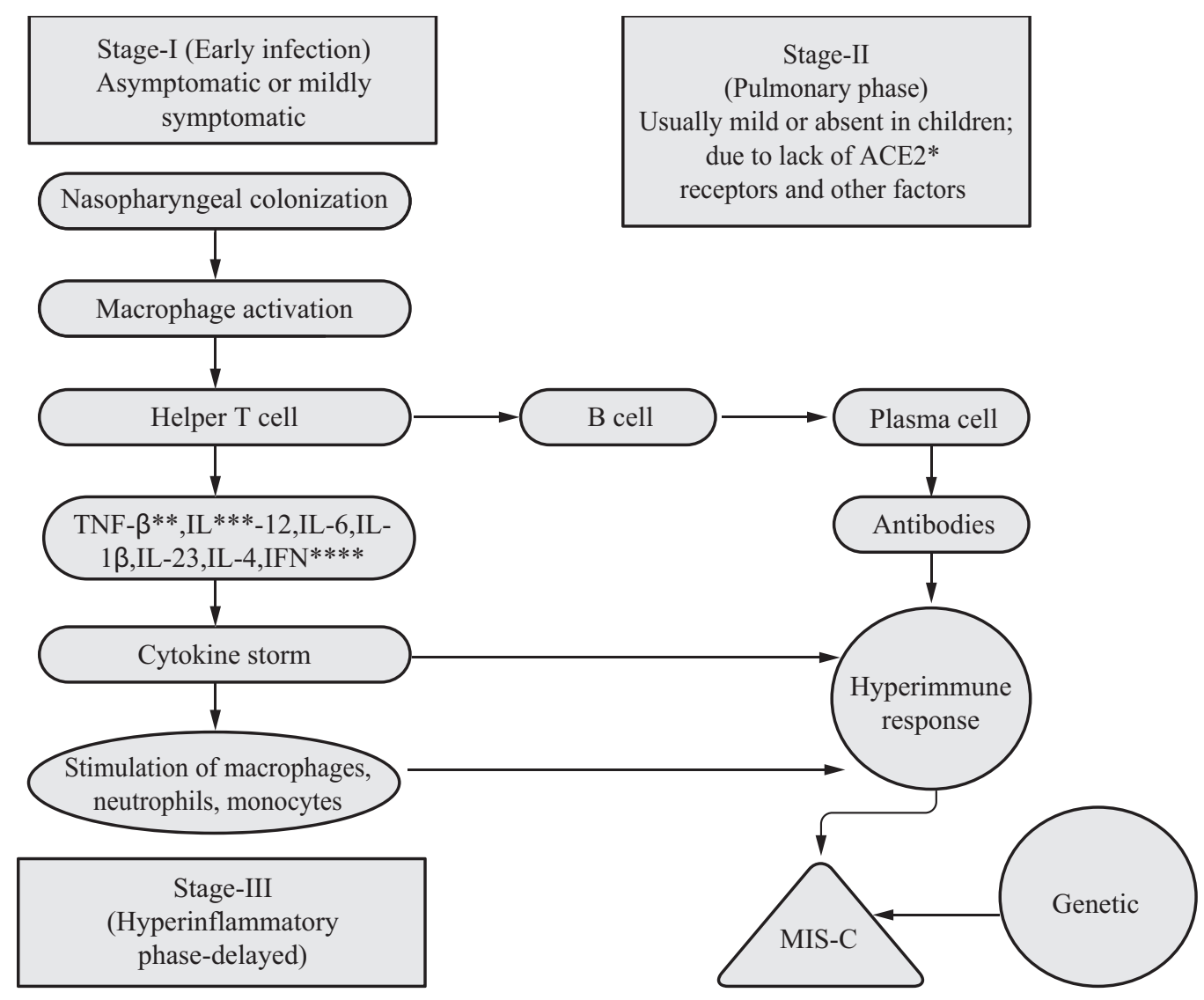

Fig.-1: Pathogenesis of MIS-C. 
*ACE2-angiotensin converting enzyme 2 receptors; $* * \mathrm{TNF}^{2}$-tumor necrosis factor ${ }^{2}, * * * \mathrm{IL}-$ interleukins, $* * * *$ IFN-interferon. ${ }^{21}$

\section{Clinical manifestations:}

Children may present with symptoms not commonly associated with Kawasaki disease, including unusual abdominal symptoms like abdominal pain, diarrhea or vomiting. ${ }^{18}$ Low blood pressure is also common. Other symptoms may include conjunctivitis, rashes, mucous membrane changes, enlarged lymph nodes, swollen hands and feet, sore throat, cough and respiratory distress, fainting, irritability and convulsion. ${ }^{12-15}$ Cardiac findings included features of myocarditis, pericarditis, valvulitis, or coronary artery abnormalities such as dilatation and aneurysms. ${ }^{15}$
It is shown in one study, the rate of coronary artery aneurysm was $1.3 \%$ in children with $\mathrm{KD}$ than $7.1 \%$ in MIS-C. ${ }^{22}$ Respiratory symptoms are not always present but often linked to shock. ${ }^{6}$ Some children display features of a cytokine storm including high serum interleukin-6 (IL-6) levels. ${ }^{23}$ Figure II shows the varied clinical features of MIS-C.

\section{Associated co-morbidity:}

United States series (78\%) and the UK (73\%) observed that most MIS-C children were without comorbidities. ${ }^{24,25}$ Obesity and bronchial asthma were found the most common co-morbidities. ${ }^{10}$ Other comorbid conditions include neurologic, hematologic, gastrointestinal or hepatic, renal, and endocrine (including diabetes mellitus). ${ }^{26}$

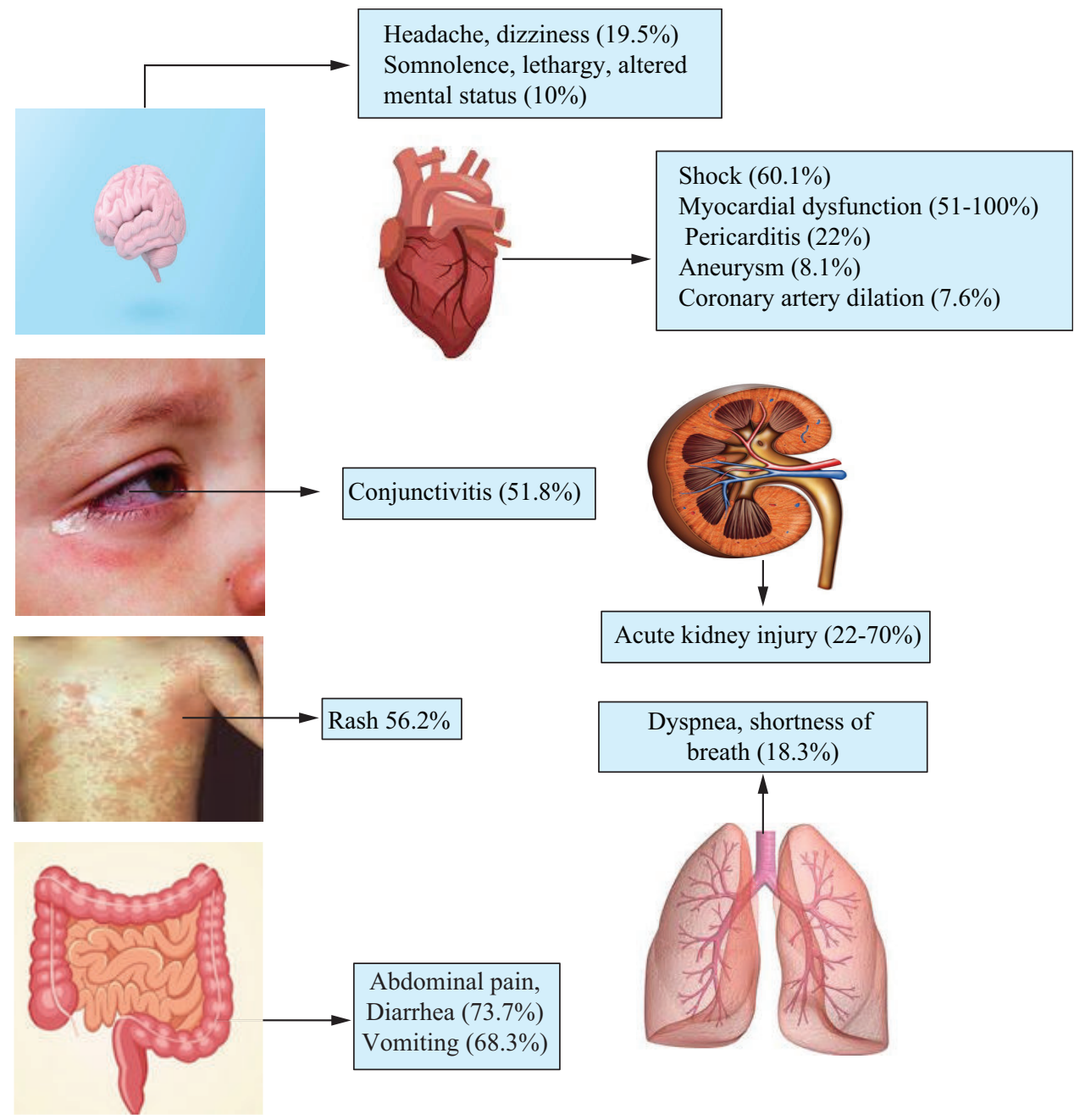

Fig.-2: Varied clinical features of MIS-C ${ }^{6,9,16,23-27}$ 


\section{Differential diagnosis:}

Differential diagnoses are broad and include other infectious and inflammatory conditions:

1. Bacterial sepsis: Children presenting with fever, shock, and elevated inflammatory markers are an essential consideration. But certain clinical features, e.g., cardiac involvement distinguishes MIS-C from bacterial sepsis. ${ }^{6,11}$

2. Kawasaki Disease (KD): Some children along the MIS-C spectrum meet complete or incomplete KD criteria. However, there are clinical and laboratory key differences between them : a) MIS-C appears to affect older children and adolescents, whereas classic KD typically affects infants and young children.

b) Gastrointestinal symptoms (particularly abdominal pain and vomiting) are very common in MIS-C but less noticeable in classic KD.

c) Cardiac involvement (myocardial dysfunction) and shock occur more commonly in MIS-C compared with classic KD.

d) MIS-C patients having elevated Inflammatory markers compared with $\mathrm{KD} .{ }^{24-27}$

Table-II shows the essential difference between MIS-C and COVID-19.

Table-II

Difference between MIS-C \& COVID-19 6,10, 27-31

\section{Parameters}

A) Clinical features

Fever

Vomiting

Diarrhea

Rash

Cough

Rhinorrhea

B) Laboratory markers

Neutrophil count

Lymphocyte count

Platelet count

Liver enzymes

Inflammatory markers

$\mathrm{C}$-reactive protein

ESR

Ferritin

Procalcitonin

Interleukin-6

Coagulation profile

D-dimer

C) Outcome

Shock

Cardiac morbidity

Intensive care admission
Usually present in all cases

More common

More common

More common

Less common

Less common

High

Decreased

Mildly decreased

Mildly elevated

Markedly elevated

Markedly elevated

Markedly elevated

Markedly elevated

Markedly elevated

Elevated

Significant

Significant

Required more

\section{COVID-19}

May or may not be present

Less common

Less common

Less common

More common

More common

Normal

Normal or decreased

Normal

Normal

Elevated

Elevated

Normal or Increased

Elevated

Elevated

Mildly elevated

Not significant

Usually absent

Less required 
3. Toxic shock syndrome - Staphylococcal and streptococcal toxic shock syndromes share many similarities with MIS-C. Microbiologic tests (SARSCoV-2 testing, bacterial cultures) are necessary to make the distinction. ${ }^{6.11}$

4. Hemophagocytic lymphohistiocytosis (HLH)/ macrophage activation syndrome (MAS): These are aggressive and life-threatening conditions with some common features of MIS-C. Cardiac and gastrointestinal involvement are less common, but neurologic symptoms are more prominent in the HLH/MAS patients. ${ }^{11}$

5. Other viral infections: manifest with multisystem involvement and/or myocarditis include EpsteinBarr virus, cytomegalovirus, adenovirus, and enteroviruses. Serology and PCR testing can distinguish these from COVID-19-related MIS-C. ${ }^{6}$

\section{Laboratory findings:}

Common laboratory abnormalities noted in the available MIS-C case series include $6,9,16,24-29$

1. Abnormal blood cell counts: lymphocytopenia, neutrophilia, thrombocytopenia

2. Elevated inflammatory markers: CRP, ESR, D-dimer, fibrinogen, ferritin, pro-calcitonin, Interleukin-6(IL-6)

3. Elevated cardiac markers: Troponin, Brain natriuretic peptide (BNP) or N-terminal -pro-B-type natriuretic peptide (NT-proBNP)
4. Hypoalbuminemia, elevated liver enzymes, lactate dehydrogenase, and triglyceride

5. Chest radiograph - pleural effusions, patchy consolidations, focal consolidation, and atelectasis were the abnormal findings.

6. Abdominal ultrasound or CT imaging - included ascites, bowel and mesenteric inflammation including terminal ileitis, mesenteric adenopathy/ adenitis, and pericholecystic edema

7. Echocardiography-findings may include depressed LV function and coronary artery (CAA) abnormalities (including dilation or aneurysm), mitral valve regurgitation, and pericardial effusion.

8. Testing for SARS-CoV-2: suspected patients should be evaluated by serology and real time reverse transcription polymerase chain reaction (rRT-PCR) on a nasopharyngeal swab.

American College of Rheumatology (ACR) recommends an investigation plan for diagnostic evaluation of MISC. ${ }^{30}$ Children with clinical features suggestive of MIS-C without shock should undergo Tier 1 investigations for initial screening and if screenings results are suggestive, then proceed to Tier 2 for complete evaluation. But if the patient presents with shock or etiology is not clear, thorough diagnostic evaluation (Tier $1 \& 2$ ) should be considered. Table III shows the ACR diagnostic evaluation of MIS-C.

Table-III

ACR diagnostic evaluation of MIS-C

\begin{tabular}{|c|c|}
\hline Tiers 1: Screening Evaluation & Tiers 2: Complete Evaluation \\
\hline $\begin{array}{l}\text { - } \text { CBC, CRP, ESR } \\
\text { Complete metabolic panel (CMP): Na, K, } \\
\text { CO2, Creatinine, albumin, total protein, AST, } \\
\text { ALT. ALP, Bilirubin } \\
\text { - SARS-CoV-2 PCR and/or serologies }\end{array}$ & $\begin{array}{ll}\text { - } & \text { BNP, Troponin-T } \\
\text { - } & \text { Procalcitonin, Ferritin } \\
\text { - } & \text { PT, APTT } \\
\text { - } & \text { D-dimer, Fibrinogen } \\
\text { - } & \text { LDH } \\
\text { - } & \text { Cytokine panel } \\
\text { - } & \text { Triglycerides } \\
\text { - } & \text { SARS-CoV-2 serology * } \\
\text { - } & \text { Echocardiogram } \\
\end{array}$ \\
\hline \multicolumn{2}{|c|}{$\begin{array}{l}\text { if the Tier } 1 \text { investigations show: } \\
\text { 1) CRP } \geq 5 \mathrm{mg} / \mathrm{dl} \text { or ESR } \geq 40 \mathrm{~mm} / \mathrm{hr} \\
\text { 2) At least one suggestive laboratory feature: } \\
\text { ALC }<1,000 / \mathrm{Ul} \text {, platelet count }<1,50,000 / \mathrm{Ul}, \mathrm{Na}<135 \mathrm{mmol} / \mathrm{L} \text {, neutrophilia, hypoalbuminemia. }\end{array}$} \\
\hline
\end{tabular}




\section{Treatment:}

The management approach should be multidisciplinary, including intensivists, pediatricians, rheumatologists, cardiologists, hematologists, and even surgeons in the suspected acute abdomen due to multisystem involvement. ${ }^{31}$ Hemodynamic instability (shock, arrhythmia), significant respiratory compromise or other potentially life-threatening complications (neurological changes like altered mental status, encephalopathy and dehydration, features of KD) are the criteria for admission in the pediatric intensive care unit. ${ }^{29,30,32}$

Antibiotic therapy: Signs and symptoms of MIS-C mimic sepsis and toxic shock syndrome. Thus, patients should receive prompt empiric broad-spectrum antibiotic therapy. Ceftriaxone plus vancomycin is an appropriate empiric regimen and piperacillin-tazobactam is an alternative option. Clindamycin is added if there are features suggestive of toxin-mediated illness. ${ }^{11,31}$

Additional therapy: Clinical presentations can overlap, and it may be appropriate to provide other interventions when more than one category of presentations is present in a MIS-C patient.

Shock: Shock should be managed according to standard protocols. Fluid boluses should be smaller (10 $\mathrm{ml} / \mathrm{kg}$ ) with careful monitoring for fluid overload signs in patients with ventricular dysfunction. Epinephrine or norepinephrine is the preferred vasoactive agent for fluid-refractory shock. In severe ventricular dysfunction, the addition of milrinone may be helpful. ${ }^{31,32}$ Extracorporeal membrane oxygenation (ECMO) or a ventricular assist device may be necessary in fulminant cases. ${ }^{33}$

\section{Immunomodulatory treatment in MIS-C:}

Children under investigation with life-threatening manifestations may require immunomodulatory treatment for MIS-C before the complete diagnostic evaluation. Intravenous immunoglobulin (IVIG) is considered a first-tier therapy to treat MIS-C children. Glucocorticoids should be used as combination therapy in patients with severe disease or as intensification therapy in patients with refractory disease. Glucocorticoids (1-2 mg/kg/day) should be administered with IVIG as adjunctive therapy to treat MIS-C patients with shock and/or organ-threatening disease. Patients not responding to IVIG and low-moderate dose glucocorticoids, high dose IV pulse glucocorticoids (10-
$30 \mathrm{mg} / \mathrm{kg}$ /day) may be considered, especially if a patient requires high dose or multiple inotropes and/or vasopressors. ${ }^{30,33,34}$

\section{Anti-platelet and anticoagulation therapy:}

Low dose aspirin (3-5 mg/kg/day) should be used in patients with MIS-C and continued until normalization of platelet count and confirmed normal coronary arteries after diagnosis. ${ }^{30}$ Additional anticoagulant therapy may be necessary for selected patients, depending on the degree of coronary arteries (CA) dilation. ${ }^{31,34}$ Therapeutic anticoagulation (Enoxaparin) has been given for patients with CA dilatation with $\mathrm{z}$ score $>10$, severe LV dysfunction (ejection fraction $<35 \%$ ) and documented thrombosis. . $^{30,33.34}$

\section{Adjunctive immune-modifying therapies:}

The use of adjunctive therapies depends on disease severity and elevated inflammatory markers. Anakinra, canakinumab, and tocilizumab are the alternative options for the treatment of refractory cases. $6.11,24,26,27,33,34$

\section{Follow-up:}

At initial visits, follow-up should be done with inflammatory markers and hematological parameters. Cardiac manifestations often improve and/or normalize before hospital discharge, but some patients have shown residual cardiac lesions. So, it is therefore recommended to follow-up for at least a year after initial diagnosis. ${ }^{29}$ Cardiac monitoring by ECG and echocardiogram should be obtained at regular intervals to evaluate arrhythmia including atrioventricular block and ventricular function with coronary artery dimensions respectively. Cardiac computed tomography (CT) or magnetic resonance imaging (MRI) may be considered if concerns of coronary artery aneurysms or ventricular dysfunction persist. As there is a high prevalence of myocardial involvement with MIS-C, restriction from physical activity for a certain period following diagnosis should also be recommended. ${ }^{35-37}$ Figure III shows the flow chart of follow-up of MIS-C patients after discharge.

\section{A scenario of MIS-C in different countries:}

Some studies were conducted in different countries like USA, UK, France to identify the clinical presentations and treatment response of MIS-C patients. These studies included clinical information, treatment options and outcome of the condition shown in Table IV. 


\section{Inpatient}

\section{Echocardiogram:}

- Repeat at 5-7 days or prior to discharge if ventricular dysfunction of dilated coronary arteries.

- Repeat at 7-10 days if within normal limit (can be done as outpatient)

ECG:

- Every 48 hours;

- If 1st degree AVB, daily ECG and continuous telemetry.

Antiplatelet: Continue aspirin following discharge.

\section{Anticoagulation:}

- If no cardiac involvement stop prior to discharge;

- If cardiac involvement continue following discharge;

- If documented thrombosis continue following discharge;

- Consider transition to apixaban at lime of discharge.

\section{0-14 days follow-up}

Labs: CBC electrolytes, renal function, liver enzymes, CRP, ESR, PCT, coagulation, viscoelastic test, D-dimer, ferritin, LDH;

- Echocardiogram;

- ECG;

- Consider Holter monitor if 1st degree AVB or arrhythmia;

- If no cardiac involvement, coronary stopping aspirin;

- If ventricular dysfunction or coronary dilation, consider stopping anticoagulation and continuing aspirin.

$\checkmark$

- Echocardiogram;

\section{4-6 weeks follow-up}

- ECG;

- Consider Holter monitor if 1st degree AVB or arrhythmia;

- If normal echocardiogram, consider stopping aspirin;

- If persistent ventricular dysfunction or coronary dilation, consider continuing aspirin.

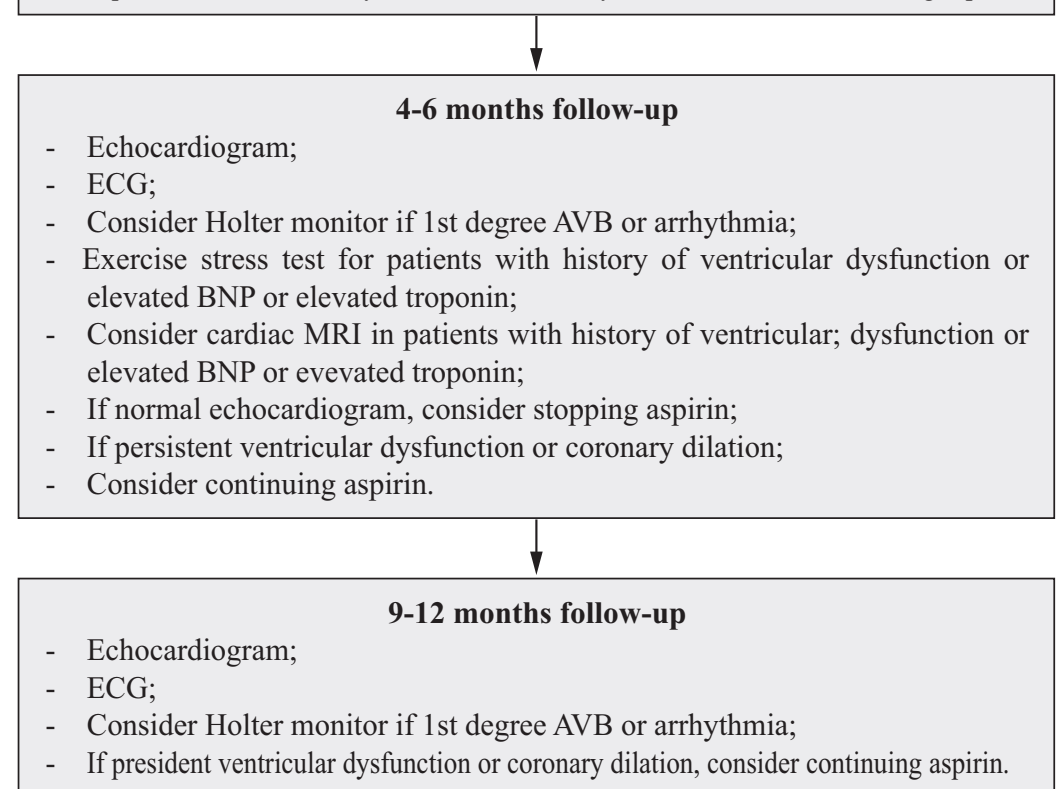

More frequent follow-up may be required if

- Ventricular dysfunction;

- Coronary artery dilation.

Fig.-3: Flow chart of follow-up of MIS-C patients after discharge. ${ }^{29}$ 
Table-IV

\begin{tabular}{|c|c|c|c|c|c|c|}
\hline \multirow{2}{*}{$\begin{array}{l}\text { Authors, country and } \\
\text { sample size }(\mathrm{N})\end{array}$} & \multirow{2}{*}{$\begin{array}{l}\text { Median } \\
\text { age }\end{array}$} & \multirow[t]{2}{*}{ Sex } & \multirow[t]{2}{*}{ Treatment } & \multicolumn{3}{|c|}{ Outcome } \\
\hline & & & & ICU & $\begin{array}{l}\text { Mechanical } \\
\text { ventilation }\end{array}$ & Death \\
\hline $\begin{array}{l}\text { Godfred-Cato, }{ }^{38} \text { USA } \\
\mathrm{N}=570\end{array}$ & 8 years & $\begin{array}{l}\text { Male } \\
(55 \%)\end{array}$ & $\begin{array}{l}\text { IVIG }(80.5 \%) \\
\text { Steroids }(62.8 \%)\end{array}$ & $64 \%$ & $12 \%$ & $2 \%$ \\
\hline $\begin{array}{l}\text { Antunez-Montes, }{ }^{39} \\
\text { Mexico, } \\
\text { Colombia, N=95 }\end{array}$ & 7 years & $\begin{array}{l}\text { Male } \\
(55 \%)\end{array}$ & $\begin{array}{l}\text { IVIG }(40 \%) \\
\text { Steroids }(28.4 \%)\end{array}$ & $21 \%$ & $9 \%$ & $2 \%$ \\
\hline $\begin{array}{l}\text { Davies, }{ }^{40} \\
\text { UK, } N=78\end{array}$ & 11 years & $\begin{array}{c}\text { Male } \\
(67 \%)\end{array}$ & $\begin{array}{l}\text { IVIG }(76 \%) \\
\text { Steroids }(73 \%)\end{array}$ & $100 \%$ & $46 \%$ & $3 \%$ \\
\hline $\begin{array}{l}\text { Belhadjer, }{ }^{41} \text { France, } \\
\mathrm{N}=35\end{array}$ & 10 years & $\begin{array}{c}\text { Male } \\
(51 \%)\end{array}$ & $\begin{array}{l}\text { IVIG }(71 \%) \\
\text { Steroids }(34 \%)\end{array}$ & $100 \%$ & $63 \%$ & $0 \%$ \\
\hline $\begin{array}{l}\text { Dhanalakshmi, }{ }^{42} \\
\text { India }, \mathrm{N}=19\end{array}$ & 6 years & $\begin{array}{c}\text { Female } \\
(58 \%)\end{array}$ & $\begin{array}{l}\text { IVIG }(79 \%) \\
\text { Steroids }(58 \%)\end{array}$ & $63 \%$ & $0 \%$ & $0 \%$ \\
\hline
\end{tabular}

\section{Bangladesh perspectives:}

A tertiary hospital study at Dhaka on 15 children with MIS-C showed all patients had fever on presentation followed by heart failure with hypotension, myocarditis and shock. Cardiac evaluation revealed coronary artery aneurysm (79.92\%), irregular coronary vascular wall (59.94\%) and left ventricular dysfunction (33.3\%). Late presentation with more cardiac involvement and delayed or inadequate treatment response were important observations of this study. ${ }^{43}$ In the fever clinic of Bangabandhu Sheik Mujib Medical University (BSMMU), 6\% of patients under 18 were RT-PCR positive. ${ }^{44}$ Another unpublished data of the department of pediatrics, BSMMU showed 31 children with MIS-C like presentations. Among them, Kawasaki Disease (KD) was eight, atypical KD was six, though this was not the KD season and the rest were MIS-C. Coronary artery dilatation was present in 6 of the 31 patients and among them, one of the patients had a giant coronary artery aneurysm. The majority of children in this cohort were RT-PCR negative similar to other published data. $8,11,24,, 25$

\section{Conclusion:}

The ongoing outbreak of multisystem inflammatory syndrome in children might be related to SARS-CoV-2. A similar outbreak is also being observed in Bangladesh like other countries affected by the COVID-19 pandemic. Early recognition is essential, followed by prompt admission to the hospital for specialist attention. It is also necessary to maintain an appropriate follow-up schedule to observe the long-term outcome. The prognosis of PMIS/ MIS-C is uncertain, given that it is a new clinical entity and understanding of the disease is still evolving.

Conflict of interest:

The authors have no conflict of interest.

\section{References:}

1. Jones VG, Mills M, Suarez D, Hogan CA, Yeh D, Segal BJ et al. COVID-19 and Kawasaki disease: novel virus and novel case. Hosp Pediatr.2020; doi: 10.1542/hpeds.2020-0123. https://doi.org/10.1542/hpeds.2020-0123 PMid:32265235

2. Viner RM, Whittaker E. Kawasaki-like disease: emerging complication during the COVID-19 pandemic. The Lancet. 2020: 295: 1741-43. https://doi.org/10.1016/ S01406736(20)31129-6 https://doi.org/10.1016/S0140-6736 (20)31129-6

3. Covid-19 demographics. Bangladesh IEDCR 24 June, 2020.

4. Liu W, Zhang Q, Chen J, Xiang R, Song H, Shu S et al. Detection of Covid-19 in Children in Early January 2020 in Wuhan, China. N Engl J Med. 2020;382: 1370-1371. doi:10.1056/NEJMc2003717 https://doi.org/10.1056/NEJ Mc2003717 PMid:32163697 PMCid:PMC7121643

5. Dong $\mathrm{Y}, \mathrm{Mo} \mathrm{X}, \mathrm{Hu} \mathrm{Y}$, Qi X, Jiang F, Jiang $\mathrm{Z}$ et al. Epidemiology of COVID-19 among children in China. Pediatrics 2020; published online March 16. DOI: https:// doi.org/10.1542/ peds.2020-0702

6. Rapid risk assessment: Paediatric inflammatory multisystem syndrome and SARS-CoV-2 infection in children". European Centre for Disease Prevention and Control. 
Available at: https://www.ecdc.europa.eu/sites/default/files/ documents/covid-19-risk-assessment-paediatricinflammatory-multisystem-syndrome-15-May-2020.pdf (Accessed 10 October 2020)

7. Centers for Disease Control and Prevention [CDC],2021(Accessed 11 August 2021)

8. Riphagen S, Gomez X, Gonzalez-Martinez C, Wilkinson $\mathrm{N}$, Theocharis P. Hyperinflammatory shock in children during COVID-19 pandemic. Lancet. 2020; 355:16071608. doi.org/10.1016/ S0140-6736(20)31094-1 https:// doi.org/10.1016/S0140-6736(20)31094-1

9. Santé Publique France. COVID-19 chez l'enfant : état des connaissances en amont de la réouverture des écoles. Paris: Santé publique France; 2020 [10/05/2020]. Available from: https://www.santepubliquefrance.fr/les-actualites/2020/ covid-19-chez-1-enfant-etat-des-connaissances-enamontde-la-reouverture-des-ecoles. (Accessed 10 October 2020 )

10. Verdoni L, Mazza A, Gervasoni A, Martelli L, Ruggeri M, Ciuffreda M, et al. An outbreak of severe Kawasaki like disease at the Italian epicentre of the SARS-CoV-2 epidemic: an observational cohort study. The Lancet. 2020. doi:10.1016/ S0140-6736(20)31103-X

11. Son MB F, Friedman K. Coronavirus disease 2019 (COVID19): Multisystem inflammatory syndrome in children. @ 2020 Uptodate (COVID-19)_Multisystem inflammatory syndrome in children UpToDate.pdf

12. Royal College of Pediatrics and Child Health Guidance: Pediatric multisystem inflammatory syndrome temporally associated with COV ID-19. Available at: https:// www.rcpch.ac.uk/sites/default/files/2020-05/COVID-19Paediatric-multisystem-inflammatory syndrome 20200501.pdf (Accessed 10 October 2020)

13. Walker DM, Tolentino VR. COVID-19: The impact on pediatric emergency care. Pediatric Emergency Medicine Practice 2020: 17: 1-27. PMID 32496723

14. Health Alert Network (HAN): Multisystem Inflammatory Syndrome in Children (MIS-C) Associated with Coronavirus Disease 2019 (COVI D-19) . Available at: https:// emergency.cdc.gov/han/2020/han00432.asp 15 May 2020. (Accessed 11 October 2020)

15. Multisystem inflammatory syndrome in children and adolescents with COVID-19: Scientific brief". www.who.int. World Health Organization. Archived from the original on 15 May 2020 (Accessed 11 October 2020)

16. Brogan P, Burns JC, Cornish J, Divakar V, Gordon JB, Gray $\mathrm{HH}$ et al. Lifetime cardiovascular management of patients with previous Kawasaki disease. Heart 2020; 106 (6): 411420. doi:10.1136/heartjnl-2019-315925. PMC 7057818. PMID 3184387 https://doi.org/10.1136/heartjnl-2019315925 PMid:31843876 PMCid:PMC7057818

17. Alunno A, Carubbi F, Rodríguez-Carrio J.Storm, typhoon, cyclone or hurricane in patients with COVID-19? Beware of the same storm that has a different origin. RMD Open. 6 (1). doi:10.1136/rmdopen-2020-001295. PMID 32423970. https://doi.org/10.1136/rmdopen-2020-001295 PMid:32423970 PMCid:PMC7299508

18. Galeotti C, Bayry J. Autoimmune and inflammatory diseases following COVID-19. Nature Reviews. Rheumatology 2020. doi:10.1038/s41584-020-0448-7. PMID 32499548. https:/ /doi.org/10.1038/s41584-020-0448-7 PMid:32499548 PMCid:PMC7271827

19. Sardu C, Gambardella J, Morelli MB, Wang X, Marfella R, Santulli G. Hypertension, Thrombosis, Kidney Failure, and Diabetes: Is COVID-19 an Endothelial Disease? A Comprehensive Evaluation of Clinical and Basic Evidence. J. Clin. Med 2020; 9(5): 1417 https://doi.org/10.3390/ jcm9051417 PMid:32403217 PMCid:PMC7290769 doi:10.3390/jcm9051417. PMID 32403217 https://doi.org/ 10.3390/jcm9051417 PMid:32403217 PMCid:PMC7290769

20. Loomba RS, Villarreal E, Flores S. Covid-19 and Kawasaki syndrome: should we really be surprised? Cardiology in the Young 2020:1-5. doi:10.1017/S1047951120001432. PMID 32412400. https://doi.org/10.1017/S1047951120001432 PMid:32412400 PMCid:PMC7322149

21. Nakra NA, Blumberg DA, Guerra AH, Lakshminrusimha S. Multi-System Inflammatory Syndrome in Children (MISC) Following SARS-CoV-2 Infection: Review of Clinical Presentation, Hypothetical Pathogenesis, and Proposed Management, MDPI.2020; 7(7):69. DOI:10.3390/ children 7070069 https://doi.org/10.3390/children7070069 PMid:32630212 PMCid:PMC7401880

22. Kil HR, Yu JW, Lee SC, Rhim JW, Lee KY. Changes in clinical and laboratory features of Kawasaki disease noted over time in Daejeon, Korea. Pediatr Rheumatol Online J. 2017;15(1):60. Published 2017 Aug 7. doi: 10.1186/ s12969-017-0192-y. https://doi.org/10.1186/s12969-0170192-y PMid:28784161 PMCid:PMC5545846

23. Rowley AH. Understanding SARS-CoV-2-related multisystem inflammatory syndrome in children. Nature Reviews. Immunology 2020. doi:10.1038/s41577-0200367-5. PMID 32546853 https://doi.org/10.1038/s41577020-0367-5 PMid:32546853 PMCid:PMC7296515

24. Whittaker E, Bamford A, Kenny J, Jones CE, Shah P, Miller O et al. Clinical Characteristics of 58 Children with a Pediatric Inflammatory Multisystem Syndrome Temporally Associated With SARS-CoV-2. JAMA 2020. Jun 8; e2010369 doi: 10.1001/jama.2020.10369 https:// doi.org/10.1001/jama.2020.10369 PMid:32511692 PMCid:PMC7281356

25. Ahmed M, Advani S, Moreira A, Zoretic S, Martinez J, Chorath $\mathrm{K}$ et al. Multisystem inflammatory syndrome in children: a systematic review. E Clinical Medicine 26 (2020). https://doi.org/10.1016/j.eclinm.2020.100527 https://doi.org/10.1016/j.eclinm.2020.100527 PMid:32923992 PMCid:PMC7473262 
26. Feldstein LR, Rose EB, Horwitz SM, Newburgwr JW, Collins JP, Newhams MM et al. Multisystem Inflammatory Syndrome in U.S. Children and Adolescents. N Engl J Med 2020; 383:334-46. DOI: 10.1056/NEJMoa2021680 https:/ /doi.org/10.1056/NEJMoa2021680 PMid:32598831 PMCid: PMC7346765

27. Toubiana J, Poirault C, Corsia A, Bajolle F, Fourgeaud J, Angoulvant $\mathrm{F}$ et al. Kawasaki-like multisystem inflammatory syndrome in children during the covid-19 pandemic in Paris, France: prospective observational study.BMJ. 2020;369:m2094 doi:10.1136 bmj.m2094 https://doi.org/10.1136/bmj.m2094 PMid:32493739 PMCid:PMC7500538

28. Hoang A, Chorath K, Moreira A, Evans M, Morton F, Burmeister F et al. COVID-19 in 7780 pediatric patients: a systematic review. E Clinical Medicine 2020. doi: 10.1016/ j.eclinm.2020.100433. https://doi.org/10.1016/j.eclinm. 2020. 100433 PMid:32766542 PMCid:PMC7318942

29. Sperotto F, Friedman KG, Son MBF, VanderPluym CJ, Newburger JW, Dionne A. Cardiac manifestations in SARSCoV-2-associated multisystem inflammatory syndrome in children: a comprehensive review and proposed clinical approach. Eur J Pediatr. https ://doi.org/10.1007/s00431020-03766-6

30. Henderson LA, Canna SW, Friedman KG, Gorelik M, Lapidus SK, Bassiri H, et al. American College of Rheumatology Clinical Guidance for Pediatric Patients with Multisystem Inflammatory Syndrome in Children (MIS C) Associated with SARS CoV 2 and Hyperinflammation in COVID 19. Version 2. Arthritis Rheumatol. doi: https:// onlinelibrary.wiley.com/doi/10.1002/art.41616.

31. Edelson DP, Sasson C, Chan PS, Atkins DL, Aziz k, Becker LB et al. Interim guidance for basic and advanced life support in adults, children, and neonates with suspected or confirmed COVID-19: from the Emergency Cardiovascular Care Committee and Get With the Guidelines-Resuscitation Adult and Pediatric Task Forces of the American Heart Association. Circulation 1-12. https://doi.org/10.1161/CIRCULATIONAHA. $120.047463 \mathrm{https}: / /$ doi.org/10.1161/CIRCULATIONAHA. 120.047463 PMid:32270695 PMCid: PMC7302067

32. Weiss SL, Peters MJ, Alhazzani W, Agus MSD, Flori HR, Inwald DP et al. Surviving Sepsis Campaign International Guidelines for the Management of Septic Shock and SepsisAssociated Organ Dysfunction in Children. Pediatr Crit Care Med 2020; 21:e52.

33. Pilania RK, Jindal AK, Guleria S, Singh S. An Update on Treatment of Kawasaki Disease. Curr Treat Options Rheumatol. 2019; 5 (1):36-55. https://doi.org/10.1007/ s40674-019-00115-z

34. Belhadjer Z, Méot M, Bajolle F, Kharachi D, Legandro A, Abaaka $\mathrm{S}$ et al. Acute heart failure in multisystem inflammatory syndrome in children (MIS-C) in the context of global SARSCoV-2 pandemic. Circulation. 2020; 382:1370-22.
doi:10.1161/CIRCULATIONAHA. $120.048360 \mathrm{https://}$ doi.org/10.1161/CIRCULATIONAHA. $\quad 120.048360$ PMid:32418446

35. Hennon TR, Penque MD, Aziz RA, Alibrahim OS, McGreevy MB, Prout AJ et al. COVID-19 associated Multisystem Inflammatory Syndrome in Children (MIS-C) guidelines; a Western New York approach https://dx.doi.org/10.1016/ j.ppedcard.2020.101232 https://doi.org/10.1016/j.ppedcard. 2020.101232 PMid:32837142 PMCid:PMC7244417

36. Canter CE, Simpson KE.Diagnosis and treatment of myocarditis in children in the current era. Circulation 129:115-128. https://doi.org/10.1161/CIRCULATIONAHA. 113.001372 PMid:24396015 https://doi.org/10.1161/ CIRCULATIONAHA.113.001372 https://doi.org/10.1161/ CIRCULATIONAHA.113.001372 PMid:24396015

37. Caforio ALP, Pankuweit S, Arbustini E, Basso C, GimenoBlanes J, Felix SB et al. European Society of Cardiology Working Group on Myocardial and Pericardial Diseases Current state of knowledge on aetiology, diagnosis, management, and therapy of myocarditis: a position statement of the European Society of Cardiology Working Group on Myocardial and Pericardial Diseases. Eur Heart J 2013; 34:2636-2648. https://doi.org/10.1093/ eurheartj/ eht 210

38. Godfred-Cato S, Bryant B, Leung J, Oster ME, Conklin L, Abrams J, et al. COVID-19-Associated Multisystem Inflammatory Syndrome in Children - United States, MarchJuly 2020. MMWR Morb Mortal Wkly Rep [Internet]. 2020 Aug 14 [cited 2020 Dec 4];69(32):1074-80. Available from: http://www.cdc.gov/mmwr/volumes/69/wr/mm6932e2. htm?s_cid=mm6932e2_w https://doi.org/10.15585/mmwr. mm6932e2 PMid:32790663 PMCid:PMC7440126

39. Yassef Antúnez-Montes O, Isabel Escamilla M, Flavio Figueroa-Uribe A, Arteaga-Menchaca E, LavariegaSaráchaga M, Salcedo-Lozada P, et al. COVID-19 and Multisystem Inflammatory Syndrome in Latin American children: a multinational study. medRxiv [Internet]. 1101 Sep 2 [cited 2020 Nov 26];2020.08.29.20184242. Available from: https://doi.org/10.1101/2020.08.29.20184242 https://doi.org/10.1101/2020.08.29.20184242

40. Davies P, Evans C, Kanthimathinathan HK, Lillie J, Brierley $\mathrm{J}$, Waters G, et al. Intensive care admissions of children with paediatric inflammatory multisystem syndrome temporally associated with SARS-CoV-2 (PIMS-TS) in the U.K.: a multicentre observational study. Lancet Child Adolesc Heal [Internet]. 2020 Sep 1 [cited 2020 Nov 25];4(9):669- 77. Available from: www.thelancet.com/child-adolescent https:/ /doi.org/10.1016/S2352-4642(20)30215-7

41. Belhadjer Z, Méot M, Bajolle F, Khraiche D, Legendre A, Abakka S, et al. Acute Heart Failure in Multisystem Inflammatory Syndrome in Children in the Context of 
Global SARS-CoV-2 Pandemic. Circulation [Internet]. 2020 Aug 4 [cited 2020 Nov 24];142(5):429-36. Available from: https://www.ahajournals.org/doi/10.1161/ CIRCULATIONAHA.120.048360 https://doi.org/10.1161/ CIRCULATIONAHA.120.048360 PMid:32418446

42. Dhanalakshmi K, Venkataraman A, Balasubramanian S, Madhusudan M, Amperayani S, Putilibai S, et al. Epidemiological and Clinical Profile of Pediatric Inflammatory Multisystem Syndrome - Temporally Associated with SARS-CoV-2 (PIMS-TS) in Indian Children. Indian Pediatr [Internet]. 2020 Aug 6 [cited 2020 Nov 20]; Available from: http://www.ncbi.nlm.nih.gov/pubmed/
32769230 https://doi.org/10.1007/s13312-020-2025-1 PMid:32769230 PMCid:PMC7678572

43. Nazrin T, Hassan MQ, Azmeri UH. Cardiac findings of multisystem inflammatory syndrome in children (MIS-C) with corona virus disease 2019 (COVID-19) SJC 2020. DOI: doi.org/10.46978/sjc.20.1.2.16 https://doi.org/ $10.46978 / \mathrm{sjc} .20 .1 .2 .16$

44. Chowdhury YJ, Rahman SA. The Higher Fatality Rate of Children from COVID-19 in Bangladesh Is it Ethnicity or Malnutrition or Else? Bangladesh Journal of Child Health 2020;44:1-3. doi.org/10.3329/bjch.v44i1.49677 https:// doi.org/10.3329/bjch.v44i1.49677 